\title{
ASSESSMENT OF THE IMPACT OF A NEW MOTORWAY CONNECTION ON THE SPATIAL DISTRIBUTION AND INTENSITY OF TRAFFIC FLOWS: A CASE STUDY OF THE D47 MOTORWAY, CZECH REPUBLIC
}

\author{
Jakub CHMELÍK, Miroslav MARADA
}

\begin{abstract}
Assessing changes in the spatial distribution and intensity of traffic flow patterns, considered one of the main direct influences of the construction of transport infrastructure, is discussed in this paper. The central element of the research is a case study assessing such changes in connection with the opening of the D47 motorway in its Lipnik nad Bečvou-Ostrava section. The aim of the study is a comparison of traffic conditions before and after the opening of the motorway. The real data on the traffic load of the motorway sections are compared with the official and our own forecast, which is based on applying a basic form of the gravity model for the given area. The results of the analysis confirmed intuitive assumptions about changes in the spatial redistribution of traffic flows.
\end{abstract}

\section{Shrnutí}

\section{Hodnocení vlivu nového dálničního spojení na prostorovou distribuci a intenzitu přepravních proudů: př́klad dálnice D47}

Př́spěvek je zaměřn na problematiku hodnocení změn prostorové distribuce a intenzity prepravních vztahů, které jsou považovány za jeden z hlavních př́mých vlivi̊ výstavby dopravní infrastruktury. Jádro př́spěvku představuje konkrétní př́pad hodnocení změn v souvislosti se zprovozněním dálnice D47 v úseku Lipník nad Bečvou-Ostrava. Cílem je především srovnání dopravních poměrư v oblasti před a po zprovoznění dálnice. Reálná data o zatížení dálničních úseků jsou komparována s oficiální a vlastní prognózou, která je založena na aplikaci základního tvaru gravitačního modelu v oblasti. Výsledky analýzy potvrdily intuitivní předpoklady o změnách v prostorové redistribuci přepravních proudů.

Key words: impacts of transport infrastructure (motorways); assessment and prediction of changes in traffic flows; gravity model; motorway D47; Ostrava region; Czech Republic

\section{Introduction}

The issue of the impact of new high-speed transport infrastructure is a widely discussed topic in fields studying various aspects of transport, mainly due to the existence of numerous and often very different viewpoints (economic, technical, environmental, political). Transport infrastructure is often considered one of the main factors in the competitiveness of national and regional economies, and the importance of the influence of transport infrastructure on regional development is not only frequently pointed out, but also often understood in divergent manners. In some cases, infrastructure is seen as a catalyst for economic development, while other authors perceive it only as one of many conditions necessary for development (e.g. Rephann, 1993; Bruinsma and Rietveldt, 1998). The impacts of a motorway on regional economic development are usually classified as indirect impacts of transport infrastructure (Bruinsma and Rietveld, 1998; Banister, Berechman, 2001; Jeřábek, Marada, 2003; Marada et al., 2010), including the influence of the motorway on the business environment, emergence of new companies, the labour market, land price, and on the overall image of a region. Assessing these factors, however, is very difficult and sometimes almost speculative, since it is not always possible to connect objectively certain changes of one factor with a change in transport infrastructure, or to define its weight precisely. In this regard, it is much easier to assess the direct impacts of transport infrastructure, which are connected mainly to real changes in the transport accessibility of certain points and often also to changes in the spatial distribution and intensity of traffic relations in a given area. The interconnectedness and causality of all direct and indirect impacts is beyond doubt.

Prior to assessing the impacts of a concrete transport infrastructure, it is necessary to evaluate responsibly the actual utility of a given construction from the point of view of the technical design and layout in the area, which have to provide the desired connection effectively. Western European countries with developed infrastructure planning have long-term experience with using comprehensive methodological procedures for the assessment of transport projects and actual impacts (e.g. Vickerman, 2000; Hayashi, Morisugi, 2000; Bruinsma and Rietveld, 1998; Lehovec et al., 2003), but their application is also problematic due to the difficult and often subjective translation of certain factors into financial figures. It can be assumed that immediately after the fall of the Iron Curtain in 1989, such mechanisms were not taken into account in the Czech Republic, which is why some projects were designed in a dubious way, as is evident in those in which construction continues in the third millennium. In this regard, it is possible to notice a 
change after the accession of the Czech Republic to the European Union (hereinafter EU), which co-finances large capital-intensive infrastructure projects from the EU budget, producing, however, more stringent requirements for proving the utility of the construction with respect to allsociety impacts. It is to be noted, however, that the inclusion of specific structures for financing from the EU budget is fully within the competence of national states, which does not always guarantee that truly important projects are supported, since other factors and mechanisms undoubtedly play a role, too. Moreover, it is important to note that in Western Europe, results of the assessment of transport infrastructure economic impact often do not correspond to political preferences (Bruinsma, Rietveld, 1998).

One of the frequently discussed structures built in the Czech Republic in the last 15 years was the D47 motorway (a section of the $\mathrm{D} 1$ motorway), connecting the Ostrava region to motorway networks of the Czech Republic and hence also to the trans-European transport network (TEN-T). This area of north-eastern Moravia and Silesia had a relatively high quality post-war road network connecting the centres of the region to serve the needs of local heavy industries. The problem, however, was the insufficient connectedness to supra-regional and international networks, which was further compounded by the dissolution of Czechoslovakia in 1993, when the Ostrava region became the most geographically remote region from the capital (e.g. Sucháček, 2005 Kuta, 2000). An effective solution for connecting to the Ostrava region was the D47 motorway (together with the $R 48^{1}$ expressway), but its construction was perpetually postponed and became a widely-discussed topic in the region among the general public, as well as political and economic leaders (Jurečka, 2003; Schejbalová, Teperová, 1999). This was mostly due to the fact that the existence of the motorway was seen as one of the requirements for the economic revitalisation of the region (e.g. Jurečka, 2003; Zahradník, 2003; Bauerová and Ramík, 2004a, 2004b; Sucháček, 2005), which faced serious structural problems due to its one-sided economic base. Sucháček (2005, p. 106) directly states that the issue of the D47 "has become during the course of the years a certain symbol of the economic, institutional and psychological circumstances of the Ostrava region restructuring..." (translation from Czech).

In connection with the D47 motorway, there was also a much discussed question of whether it was necessary for the route to run directly through the city of Ostrava, as was planned since the $1960 \mathrm{~s}$ in government documents concerning the development of transport networks in the Czech Republic (Prášil, 2007). A number of environmental groups, in particular, voiced the opinion that the D47 motorway in the Bělotín-Ostrava-Czech-Polish state border section was not justified because it was duplicated by the R48 expressway, and that it would be possible to connect the Ostrava region by modernising the I/58 Příbor-Ostrava road or the R56 Frýdek-Místek-Ostrava expressway. In that case, the transit traffic to Poland would be realised over the already-existing Český Těšín-Chotěbuz route. This opinion was opposed, for example by Řehák (2004), who applied gravity modelling for simulating traffic relationships between the Czech Republic and its neighbouring states. Based on his results, he stated that the international connection between the Czech Republic and Poland via
Ostrava would be significantly stronger than the preferred connection through Ceský Těšín, and that the modernisation of the $\mathrm{I} / 48$ road would not meet the purpose. The question of the construction of the D47 over the R48, favoured in the past, was also addressed by the Czech Supreme Audit Office (hereinafter SAO), which investigated whether the preference for the D47 was based on objective circumstances. SAO came to the conclusion that no assessment of either project had been made in which the Czech Ministry of Transport and the Road and Motorway Directorate of the Czech Republic (hereinafter RMD) identified and quantified the socio-economic benefits, and justified prioritising the D47 project (Auditing Action 04/25, SAO Bulletin, 2005). The absence of any studies demonstrating the effectiveness and societal benefits of the D47 was confirmed by the RMD from the authors' questions.

At present, the D47 is already open and it is therefore possible to evaluate its impacts, at least partially. The authors do not aim to evaluate the much-debated indirect impacts of the D47 on the economic development of the Ostrava region, which are moreover difficult to identify given the short period of time the motorway has been open. The degree of the motorway influence on the monitored indicators and their selection remains debatable. Rather, this paper focuses on a basic assessment of changes in the spatial distribution and intensity of traffic flow, which are considered some of the main direct influences of transport infrastructure construction, especially new motorways. In general, the objective of this paper is to describe basic possibilities for assessing the direct impact of motorways on transport interaction in the given area, as well as their forecasts, which is important for evaluating the utility and efficiency of the infrastructure. A brief comparison is made of these factors in the Czech Republic and in Western Europe. The core of this research is a case study for assessing changes in the spatial distribution of traffic flows intensity brought about by the opening of the D47 motorway. The primary goal is to compare traffic conditions before and after the opening of the highway, based on data from the national traffic censuses in 2000, 2005 and 2010 (National Traffic Census [hereinafter NTC], 2000, 2005, 2010). Real data on the traffic load of motorway sections will be compared to the forecast made by the investor (D47 Project Information, RMD, 2012), and to our own projections based on an applied basic form of the gravity model (Chmelík, 2008).

Another partial goal is to assess the use of typical geographic applications for this type of analysis. It is by comparing real and forecasted data that we can identify the main drawbacks of approaches based on modelling, which cannot always anticipate the real impact precisely. In this context, it is of course important to note that since the D47 was not connected by motorway to the Polish A1 motorway at the time of the last census (NTC, 2010) $)^{2}$, it can be assumed that any prediction will be partially distorted and will not correspond to the foreseeable situation. This is because the north-south transit road traffic, which is included in the prediction for the motorway, was at that time still routed through the original Český Těšín-Chotěbuz vein. This fact, though, can also be considered an advantage in a certain sense, as this situation allows for the identification of the real transport potential of the Ostrava region in a narrower definition, i.e. regional centres for which the motorway is

\footnotetext{
${ }^{1}$ The expressway in the Bělotín-Nový Jičín-Frýdek-Místek-Český Těšín-Czech-Polish state border section.

2 The Czech D47 was connected to the Polish A1 in 2012 for passenger cars, and in 2014 also for heavy goods vehicles.
} 
already useful to save time. In addition, this situation allows for the elimination of one of the methodological problems, namely the lack of information on the ratio of transit traffic flows to the overall traffic load, which represents a significant part of the actual as well as predicted traffic flow in a number of motorway sections.

Analogically to the identification of the indirect impact of the D47 motorway on the development of the Ostrava region, this research does not cover in detail the above-mentioned issue of the utility of the new motorway connection with Ostrava, as this issue requires a more complex assessment beyond the scope of the work. Therefore, arguments for the necessity of construction are described only briefly from other studies. At the same time, however, the authors believe that in comparison with other projects in the Czech Republic, the D47 motorway, which connects to the second largest agglomeration of the Czech Republic, is far more significant and its existence is rational. On the other hand, it is to be noted that the present value of the intensity of traffic on the D47 route, and even in the six-lane Lipník nad Bečvou-Bělotín ${ }^{3}$ section carrying all north-south transport, is a cause for reflection. It should be emphasized once again, however, that this situation can be connected to the incomplete transit functionality of the motorway at the time of the study.

\section{Assessing direct impacts of motorways on transport relations}

The issue of identifying and evaluating the direct impact of linear transport infrastructure is addressed relatively often and not only as a part of transport-geographical research. This is mostly due to the influence of the timespace convergence of centres. This convergence is connected to a lower resistance to travel, which is caused both by a decrease in the time needed for reaching a certain point due to new and usually high-speed infrastructure, and by a decrease in transportation costs (Gutierrez, Urbano, 1996; Vickerman et al., 1999; Rietveld, Vickerman, 2004; Preston, O'Connor, 2008).

For expressing potential spatial impacts of the new transport infrastructure on the pattern of traffic flow intensity, it is possible to use the concept of generative and distributive effects ${ }^{4}$ (for more details, see Rietveld, Bruinsma, 1998), which was primarily applied to identify changes in the localisation of economic activities. The generative effect instigates completely new activities, which analogically mean generating new traffic as to the direct impact of motorways. This effect is directly related to the decrease in the time needed for travel and the consequent new possibilities for each of the newly-connected points and positive stimulation of the mobility of persons and goods, coupled with growing employment opportunities and new types of activities. In terms of indirect impacts, though, the aspects of improved mutual accessibility do not often bring only positive effects, since a good quality connection can increase competitive pressure on the local market in the newly-connected area and gradually "drain" the activities from the weaker region (Jeřábek, Marada, 2003). The distributive effect causes only a shift of the traffic, usually in favour of the new motorway, which has a positive influence on regional centres previously overburdened by transit traffic.

In this context, it is possible to say that as to significant projects, only those with a strategic potential for the generative effect should be considered, while in the case of a need for improving a current unsuitable traffic situation, it is more efficient to seek a solution by means of traffic redistribution. Such a polarized division is hardly ever the case, however, and it can be assumed that the structure of traffic intensity in the new sections is at all times partly caused by the generative effect (new traffic participants) and partly by traffic shifted from other roads which are less convenient than the new connection. The assumption of a shift of some of the traffic flows to the new connection closely relates to the so-called intervening opportunity, which had been stated as a part of spatial interaction theory by Ullman (Ullman, 1956, cited in Rodrigue et al., 2006). From the methodological point of view, distinguishing the effects (generative or distributive) remains problematic, as it is limited by the nature of the databases and by the methods. This happens not only when assessing the indirect impacts (such as motivation and preference of a certain location for economic activities), but especially in assessing the impacts of a specific transport infrastructure project on traffic relations in the area.

Data on individual car traffic, which generates most of the interactions on the road network with regard to passenger transport, are rather limited. The main and often the only commonly available data on individual car traffic are traffic intensities on individual counting sections in which the vehicles are counted. In the Czech Republic, this information is provided by the RMD, which conducts a national traffic census every five years, in which information can be found on the traffic intensity according to different vehicle types (cars, trucks, motorcycles, buses) on Czech roads and motorways. Information on the sections of motorways and expressways with automated traffic counters is provided in a shorter interval of time. The value of the traffic load on a given section is in principal the aggregated result of the behaviour of all traffic participants, who make their decisions about where to travel according to their personal needs (Brůhová-Foltýnová et al., 2008), while the beginning, aim, frequency or purpose of their journey is not known.

When identifying the influence of a new connection, the most limiting absence of information is seen in the aim of the journey (i.e. the structure of traffic intensity on a given section according to the beginning and the end of the journey), with which it would be possible to find out concrete volumes of the redistributed traffic. Data on the direction relationships, including the prediction of their change caused by changes in the network, are usually replaced by estimates based on both basic gravity models (Řehák, 1997, 2004; Halás, 2005; Kraft, Blažek, 2012) and transport models generated by specialized software. The gravity model is one of the most used tools in traditional transport geography research. The

\footnotetext{
${ }^{3}$ According to the RMD, the large-scale six-lane design was adopted because of the junction with the D1 motorway (to Přerov) and the R35 expressway (to Olomouc) on one side, and the D47 motorway (to Ostrava) and the R48 expressway (to Nový Jičín) on the other side. At the same time, the study for RMD (ADIAS, 2001) states that in this section the motorway has a significant extra capacity.

${ }^{4}$ In traffic engineering disciplines, "induced transport" (generative effects) and "shifted transport" (distributive effects) are commonly used, referring essentially to these effects.
} 
quite simple use for assessing changes in spatial interactions in the transport network (e.g. building a new highway) is the main advantage of this model. In the Czech Republic, studies by Řehák $(1992,1997,2004)$ are well recognised using the planned road system based on various types of gravity model. In international research, the gravity model is still used namely for basic travel demand estimates, for example in the field of the airline traffic volume estimation (e.g. Grosche et al., 2007; Matsumoto, 2007).

In the Czech Republic, the prediction of traffic intensity is formally bound by technical conditions. From these technical conditions, the prediction is made either by way of a growth coefficient assuming stable development of intensity on the roads of the same class, or by a mathematical model of the traffic flow on a network, which takes into account factors causing unstable development of transport relations (Bartoš et al., 2010). In the case of an existing transport connection, the beginning and the end of the journey can also be identified by simple analytical methods, such as the frequently-used transport divide method (Hůrský, 1978; Marada, 2008; currently Kraft et al., 2014). According to this method, a corresponding value of traffic intensity is assigned to each of the sections connecting the regional centres. In all cases, the data of course refer to the number of vehicles and not to the number of passengers, which usually complicates a comparison with, for example, data on the number of persons using a specific mode of public transport. In connection with the above facts, a question remains whether detailed data on the direction of individual transport passenger mobility are necessary, considering the high financial cost for the technical and organisational aspects of their collection, or whether the models give us satisfactory results. They should at least identify a basic structure of the directions for a given section, capture the major trends and predict the order of spatial impacts on the network, usually based on changes in the time required to reach a certain destination.

High quality information on current and expected traffic flows should be one of the main inputs in the process of assessing the priorities of needs when evaluating transport infrastructure construction, since it is evident that the transport needs of people generate a justified demand for improving the transport situation. In countries with developed transport infrastructure, the main method applied for assessing transport infrastructure building projects has for a number of decades been cost-benefit analysis (further CBA), which is often combined with a multi-criteria analysis comparing multiple projects (see the overviews in Hayashi, Morisugi, 2000; Quinet, 2000; Morisugi, 2000; Lee Jr., 2000; Gühnemann et al., 2012). The criterion capturing best the direct impacts of a project is economy of time, which is often one of the most important indicators. In the UK, for instance, it is considered the main criterion, together with the reduction of traffic accidents (Vickerman, 2000). Frequently connected to the criterion of time economy is a necessary forecast of transport demand, which is usually based on national transport models in which the impact of a new project on the current intensity distribution is simulated according to changes in the required inputs. The prediction is closely connected to the indicator of time value for different categories of passengers. This indicator is important for assessing economic impacts and for expressing time economy in financial figures - the time value based on qualitative survey research (Hayashi and Morisugi, 2000). A practical example of the combination of cost-benefit analysis and multi-criteria analysis, including the ranking of individual projects, can be found, for example, in Guhnemann et al. (2012).

In the Czech Republic, the situation is somewhat different because the hierarchy of priorities of high-capacity road infrastructure construction was never a long-term conceptual solution, from the point of view of investment benefits. In this regard, reference can be made to the SAO's audit conclusions, which state that the Ministry of Transport, being the public administrative body responsible for formulating transport policy, did not assess the societal benefits of any of the high-capacity road infrastructure projects described in the concept paper, Proposal for Development of Transport Networks in the Czech Republic until 2010. According to the SAO investigation, the only criterion for the inclusion of a project was the value of traffic load on roads operating in the route of the planned motorway or expressway, without stating any priority for projects in terms of strategic goals. Also taken into account were projects, which had been prepared in the past (Control Action 02/10, SAO Bulletin, 2003). The lack of methodology for assessing transport infrastructure project benefits is pointed out by Viturka et al. (2012), where it is also mentioned that the current regime gives preference to the factor of zoning preparedness (as well as negotiability at consulting points) over society-wide benefits. The authors offer their own ranking of significant projects based on the chosen utility assessment methodology. Among other events, in response to criticism by SAO, civic initiatives and the European Commission, the Ministry of Transport began in 2011 to develop a project called "Transport Sector Strategy, $2^{\text {nd }}$ Phase", which states individual priorities in transport infrastructure construction to be co-financed by EU (in more detail see www.dopravnistrategie.cz).

Within the procedures of project assessment, the first step was to construct a transport model of the Czech Republic which takes into account current conditions and limits, and, based on the scenarios for the development of each model, components predictions were made for the years 2020 and 2050. The analytical part, in which the transport demand and its expected development should primarily be identified, is the basis for the designing part, in which the priorities for transport infrastructure construction in the Czech Republic are stated, and multicriteria evaluation is applied. The results confirmed intuitive premises: the greatest number of points were given to the missing part of the R1 Prague ring between Běchovice and the D1 motorway, followed by the section of the D1 between Ŕíkovice and Přerov, and the missing sections of the R35 expressway (see more details in Vachtl et al., 2013).

\section{Assessing traffic intensity changes in the affected area: Case study - D47 motorway}

For the assessment of changes in traffic intensities in the area affected by the opening of the D47, the data from the traffic census on Czech motorways and roads were used. The census is conducted by RMD every five years. The required time series were obtained by using data from 2000, 2005 and 2010 (NTC, 2000, 2005, 2010), bearing in mind, though, that the 2010 data do not necessarily reflect the change in route selection preference of all potential D47 users, since the service was limited in part of the year 2010, and also due to the then-ongoing process of "acclimation" to the new alternative. From this point of view, it will be results obtained in 2015 that will be significant, as at that time the route preferences will be stabilized. The data used 
were the basic data showing the annual average of daily traffic (AADT) indicating the number of passenger vehicles in 24 hours on a given section ${ }^{5}$. The methodological approach first involved the definition of the affected road network (see Fig. 1), in which traffic conditions could be influenced by changes in route preference connected to the opening of the motorway. The monitored network was subsequently divided into sections (edges between major centres or nodes), for which relevant values of traffic intensity were defined based on the traffic census data. The procedure consisted in finding the point of the lowest traffic intensity between two centres or nodes, i.e. finding a section in rural areas with the lowest traffic load. These least-frequented sections between centres should theoretically best reflect the real contact between them, since it can be postulated that this eliminates the traffic relations connected to reaching facilities, which are more influenced by regular short-distance travelling (e.g. more intensive contacts are to be identified at counting points located between the centre of a town and its surrounding area).

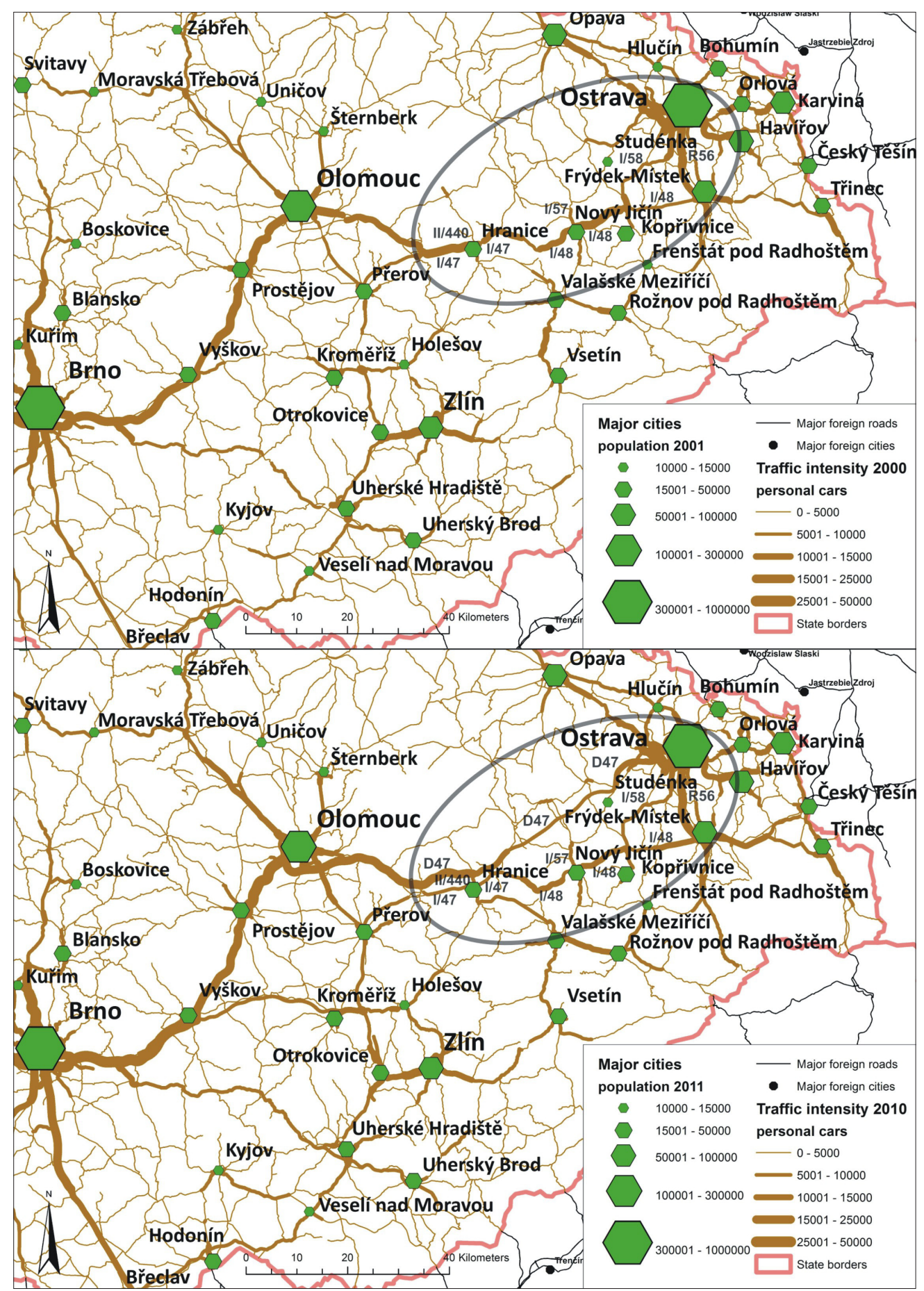

Fig. 1: Determination of relevant road network, including traffic volume (2000 and 2010)

Sources: NTC 2000, 2010

\footnotetext{
${ }^{5}$ Focusing mainly on the analysis of passenger vehicles is necessary due to the methodological changes in the heavy goods vehicles census between 2005 and 2010. The use of passenger cars is simultaneously preferable for their greater flexibility and possibility to use the unfinished D47 at a higher rate than trucks in 2010.
} 
This applied concept of the point with the lowest traffic intensity is one of the analytical methods used by the transport geographer J. Hůrský (1978) for identifying traffic divisions. Given the need to compare different sections in three time series, it was always necessary to monitor the same census section, since in some cases during the years the lowest traffic point shifted on the monitored edge of the network if it had more sections. Since the focus is on the assessment of the D47, the basic census section was the point with the lowest traffic intensity as of the year 2010, and this section was subsequently compared to the identical section in 2005 and 2000, provided that it had existed and had been monitored at that time. It is necessary to point out a number of partial limitations of this procedure and methodology (such as the selection of a representative section with the lowest traffic, general impact of transport behaviour changes on traffic intensity without the influence of the new motorway, the lack of data on directional relationships of each section, and the consequent lack of data on the ratio of local, regional and transit traffic flows, etc.). These limitations can eventually influence the final assessment, which is in some cases supported by subjective decisions of the authors. The partial limitations, however, do not preclude structural and chronological comparison, since the results of the censuses obtained in different years are comparable (a similar methodology had been used).

For assessing the D47 degree of impact on the changes in traffic relations, it was useful to select sections, which had been used prior to the opening of the motorway, mostly for connecting the Ostrava region with other regions of the Czech Republic and also for transit connection, especially in the south-west-north-east axis. In particular these were the roads I/58 in the Ostrava-Příbor section, R56 in the Ostrava-Frýdek-Místek section, R/I/48 in the FrýdekMístek-Bělotín section and I/47 in the Bělotín-Lipník nad Bečvou section. Results of the traffic intensity in the monitored sections in each year confirm the intuitive premises of the change in the spatial distribution of traffic relations in the affected area. This is evident from Table 1 , which contains the values of intensities in sections which were previously (during the censuses of 2000 and 2005) used for supra-regional contacts, now redistributed to the D47 (the 2010 traffic census). In these sections, it can be noticed that after the previous growth or stagnation between the years 2000 and 2005, the traffic intensities decreased significantly (by several dozen percentage points) between 2005 and 2010, especially in the case of the Ostrava connection by the road I/58 (decrease by $27.4 \%$ ) followed by the I/48 (decrease by 10.6-23.6\%) and the I/47 (decrease by $43.4-57.9 \%$ ) in the direction of Olomouc.

Changes are also evident in the sections of roads $\mathrm{I} / 57$ and II/440, which are concurrently fulfilling the role of feeder roads to the motorway in the direction of Nový Jičín and Hranice, where, by contrast, the traffic intensity has increased. From the point of view of traffic shift in favour of the D47, the values for the lowest traffic points in the OstravaFrýdek-Místek section remained surprisingly practically unchanged (decrease by $4.0 \%$ ) between 2005 and 2010. From this, it can be deduced that the section was not preferred as a connection between the Ostrava region and the main network of the Czech Republic even earlier, despite its high quality and large capacity. On the other hand, it is also possible that the difference in intensities caused by the shift of traffic to the D47 is not evident because of increasing contacts between Ostrava and Frýdek-Místek. This is further intensified by residential buildings near the Beskydy Mts., whose inhabitants usually work in the regional centre and therefore mostly use the R56 for individual transport given a large percentage of car transport. These arguments are, however, only speculative, since they cannot be confirmed using the available database, which does not capture destinations of traffic relations which constitute aggregated traffic intensity. In order to find out actual information on the traffic load structure in a specific section, it would be necessary to conduct a costly traffic survey that would be extremely difficult for individual car transport.

Although the traffic census data concerning the heavy good vehicles are affected by methodological changes between the years 2005 and 2010, the monitored sections were also calculated for this type of road transport modes. From this point of view, the results have to be used more carefully because the causality of the main changes can be connected with the variable quality of the data. In general, it is possible to suppose similar changes in the traffic distribution of all road transport modes. The results of the basic analysis confirmed analogous changes mainly in the Ostrava-Příbor-Nový Jičín-Hranice axis, where the traffic intensities decreased significantly (more than in the changes of passenger vehicles) between 2005 and 2010, following previous growth in 2000 and 2005. The greatest changes were identified in the Bělotín-Lipník nad Bečvou section (decrease by ca. $80 \%$ ), which was practically fully opened also for heavy goods vehicles in 2010. Changes are also obvious in

\begin{tabular}{|l|r|r|r|r|c|}
\hline \multirow{2}{*}{\multicolumn{1}{|c|}{ Section }} & \multicolumn{3}{c|}{ Traffic intensity (AADT) } & \multicolumn{2}{c|}{ Change (\%) } \\
\cline { 2 - 6 } & 2000 & 2005 & 2010 & $2000 / 2005$ & $2005 / 2010$ \\
\hline R56 Ostrava - Frýdek-Místek & 13,906 & 21,877 & 21,002 & 57.3 & -4.0 \\
\hline I/58 Ostrava - Příbor & 9,858 & 10,069 & 7,311 & 2.1 & -27.4 \\
\hline I/48 Frýdek-Místek - Příbor & 8,526 & 9,893 & 8,840 & 16.0 & -10.6 \\
\hline I/48 Příbor - Nový Jič́́n & 16,002 & 18,997 & 14,523 & 18.7 & -23.6 \\
\hline I/R 48 Nový Jičín - Bělotín & 10,239 & 12,114 & 9,711 & 18.3 & -19.8 \\
\hline I/57 Hladké Životice - Nový Jičín & 2,468 & 2,797 & 4,401 & 13.3 & 57.3 \\
\hline I/47 Bělotín - Hranice & 13,403 & 13,947 & 5,866 & 4.1 & -57.9 \\
\hline I/47 Hranice - Lipník nad Bečvou & 15,377 & 16,839 & 9,526 & 9.5 & -43.4 \\
\hline II/440 MÚK Hranice - Hranice & 2,935 & 2,576 & 5,001 & -12.2 & 94.1 \\
\hline
\end{tabular}

Tab. 1: Traffic intensity values of passenger vehicles in the monitored sections of the affected road network Sources: NTC 2000, 2005, 2010; authors' calculations 
the sections of roads $\mathrm{I} / 58$ (decrease by nearly $60 \%$ ) and $\mathrm{I} / 48$ (decrease by ca. 50\%). On the other hand, in case of the Ostrava connection by the road R56, the increased (20\%) heavy vehicles transport between 2005 and 2010 was hardly noticed. In the Ostrava-Frýdek-Místek section, different results for R56 were identified in assessing changes in passenger car intensities as well.

\section{Traffic intensity on the D47 motorway: forecast vs. reality}

The actual utilisation of the new D47 motorway, which has changed the route preference for many connections and especially connections with supra-regional centres, can be again demonstrated by data from the 2010 traffic census (NTC, 2010). Analogically to the procedure described in the previous section, elements of the motorway were roughly determined (see Fig. 1), and for each of them the census section with the lowest traffic intensity was identified. The obtained real values of traffic intensities for the year 2010 were subsequently compared with the predictions of traffic load for 2010, 2030 (both derived from the 2000 data) and 2040 (based on data from 2010), which are presented by RMD in their information materials (RMD, 2009, 2012) ${ }^{6}$. Again, only those census sections with the lowest predicted values were taken into account. Finally, in the following section the real and predicted values are compared with the results of the authors' own predictions, which were based on a gravity model applied to the given area.

The values of real traffic intensities (see Tab. 2) on the D47 ranged from about 13,000 vehicles in the section with the lowest traffic load to 22,000 vehicles in the section with the highest traffic load. Compared with the RMD prediction based on the 2000 data and followed by adjustments according to growth coefficients, real values were approximately by 5,000 10,000 vehicles lower than expected in 2010 . The same can be seen in the case of predictions for more distant dates, when the traffic intensity grew together with the assumed further growth of motorization, an increased ratio of individual car transport in the overall passenger transport performance and more flexible freight transport. Even if this is a long-term perspective, it is already possible to point out the relatively high values of traffic intensity predicted for 2040 based on the 2010 data, when the expected daily intensity for the section of the D47 between Lipník nad Bečvou and Bělotín is expected to reach over 50,000 vehicles (in 2030 approx. 35,000).

It may be noted for comparison that traffic intensities on the busiest motorway in the Czech Republic (D1) in the section between Mirošovice (exit 21) and Kývalka (exit 182), which is now already less burdened by regular traffic between Prague and Brno than it was in 2010 , are by $10,000-15,000$ vehicles lower than those predicted for the D47 Lipník nad BečvouBělotín section. The current traffic intensity in this section is comparable to the intensity of the D11 motorway and the R10 road on the borders of the Central Bohemia region, or the D2 motorway between exit 11 and Břeclav (exit 48). The intensity of the Berlotín-Ostrava section is then comparable to the traffic load on the R4, R6 and R7 expressways at a distance of approximately $20 \mathrm{~km}$ from the administrative borders of Prague. It is also comparable to the most frequented first-class roads (such as the road I/3 and I/35). Based on what has been stated above, it is possible to conclude that the predictions of traffic intensities for the D47 presented by RMD before the construction, were overestimated as compared with the already known real data. However, it is necessary to objectively recall that the predictions were construed for the whole D47 route, i.e. counting on its connection with the Polish A1, which had not been finished by the time of the 2010 census.

\begin{tabular}{|l|c|c|c|c|c|}
\hline \multirow{2}{*}{\multicolumn{1}{|c|}{ Section }} & \multicolumn{2}{|c|}{$\begin{array}{c}\text { Real traffic } \\
\text { intensity } \\
\text { (AADT) }\end{array}$} & \multicolumn{2}{|c|}{ Prediction of traffic intensity by RMD } & $\begin{array}{c}\text { Own prediction } \\
\text { of traffic } \\
\text { intensity }\end{array}$ \\
\cline { 2 - 6 } & 2010 & 2010 & 2030 & 2040 & 2015 \\
\hline D47 Ostrava - Hladké Životice & 13,189 & 18,000 & 21,900 & 33,000 & 33,260 \\
\hline D47 Hladké Životice - Bělotín & 13,761 & 16,900 & 20,600 & 32,000 & 30,220 \\
\hline D47 Bělotín - MÚK Hranice & 16,500 & 29,800 & 36,300 & 53,000 & 31,440 \\
\hline D47 MÚK Hranice - Lipník nad Bečvou & 22,561 & 29,500 & 35,900 & 52,000 & 31,440 \\
\hline
\end{tabular}

Tab. 2: Real and predicted traffic intensities on the monitored D47 sections. Sources: NTC 2010; RMD 2009, 2012; authors' own calculations

Note: All values include information for the volume of all road transport vehicles

\section{Gravity model application on the affected area}

Our own prediction, which, by means of a comparison with the "official" RMD predictions and real data, can contribute to the discussion, is based on the gravity model (for more detail see Chmelík, 2008; Chmelík, 2008, quoted in Marada et al., 2010). The application of the gravity model is still useful for studying traffic relations, especially when identifying basic interaction intensities in space or simulating changes of traffic relations distribution caused by a new route. A general prerequisite for modelling is the assertion that a certain spatial distribution of regional centres together with a certain configuration of transport network, objectively determines the basic features of spatial interaction in a given area (Ǩehák, 1992). For the application itself, we used a basic form of the model (e.g. Řehák, 1992; Haggett, 2001; Black, 2003; Rodrigue et al., 2006), which is for each pair of centres determined by the general formula:

$$
\mathbf{X}_{i j}=\left(\mathbf{M}_{i} \times \mathbf{M}_{j}\right) / \mathbf{D}_{i j} \mathbf{b}
$$

where $\mathrm{X}_{i j}$ is a dimensionless expression of the strength of mutual relations between the centres $i$ and $j$, i.e. the

\footnotetext{
${ }^{6}$ Real values for all transport volumes were used for a comparison in the year 2010 because the prediction of traffic load by RMD was based on total traffic load. The results may be affected by methodological changes in the traffic census of heavy goods vehicles between 2005 and 2010 .
} 
interaction or the traffic relation between these two centres; $\mathrm{M}_{i}$ and $\mathrm{M}_{j}$ are so-called masses of the centres; $\mathrm{D}_{i j}$ is a distance between the centres; and $b$ is a parameter determining the distance typical of a given task.

This model monitors the major road network influencing traffic relations in the Ostrava region, whose territory corresponded to the meso-region of Ostrava determined during the division of the Czech Republic into sociogeographical regions in 2001 (Hampl, 2005). The mutual relationships between micro-regional centres, as well as between main centres of the Ostrava region and interregional and national centres of the Czech Republic and its neighbouring states, are combined on the monitored road network. In the case of the Czech Republic, the mass of the centre in this model is represented by the indicator of complex size (an aggregate based on the number of inhabitants and jobs, for more details see Hampl, 2005), and the number of inhabitants in the case of centres in another state. The model is considered symmetrical with the assumption that the emissivity and attractiveness of each of the monitored centres with a mass are directly proportional to the mass of the centre. The distance between the centres is expressed as time required for the travel, with road network changes in the surveyed years being taken into account.

The model was at first constructed for the years 1990 and 2000, based on data from the national traffic census. For each edge of the monitored network, we used the intensity value, which corresponded to the point with the lowest traffic load between two centres. The aim of the calibration was to find such values for the distance influence parameter $b$, with which the real values for the surveyed years would correspond to the model values as much as possible. After having obtained these parameter values from the calibration for $1990(b=2.4)$ and $2000(b=2.1)$, which corresponded to the expected transport trends (decreasing importance of distance on transport interactions, increasing transport intensities), it was possible to determine the parameter used in model construction for the period after $2010(b=2.0)^{7}$. This model is based on the form of a reference equation used for the year 2000 , while it also already includes expected changes in the temporal distance between the centres due to the construction of D47. At the same time, the predicted values for each of the edges were adjusted by way of the divergence of real (for 2005) and theoretical (model-based) traffic loads, so that they would correspond to actual relations in the system existing in 2005 as much as possible. This procedure is obviously only a very simplified prediction and features all of the problems connected with the application of basic interaction models (distance being the only differentiating factor; theoretical assumption of a stable regional system; the very settings of the model, including the subjective perspective of the researcher, etc.). Therefore, it is necessary to perceive the obtained results of the predicted intensities only as a rough estimate, which is nevertheless still valuable, especially if compared with analogical outputs.

The model we used generated results of expected traffic load for the D47 (see Tab. 2), for which the value of intensity for the complete monitored section was slightly over 30,000 vehicles per day. This traffic load corresponds to the values given by RMD (for 2010 and 2030) in the prediction for the section Lipník nad Bečvou-Bělotín, which is used for all long-distance or transit transport in the south-west-north-east axis. The real traffic load in 2010 was, however, lower than both of the predictions by approximately $10,000-15,000$ vehicles. In contrast to the "official" prediction, our model overestimated the BělotínOstrava section, predicting the traffic load to be higher by 10,000-15,000 vehicles. Moreover, real values for this section in 2010 were lower by approximately 20,000 vehicles. As mentioned with respect to the RMD forecast, it is also necessary in this context to note that our model was constructed upon the assumption that the motorway would be completed and would provide not only a connection with the domestic network but also with Poland, which was not achieved by the time of the 2010 census. Some reasons for such a high traffic load model values can be found mainly in the overestimated traffic connections with the Katowice conurbation, the realistic connection of which to the Ostrava region and other metropolitan regions in the Czech Republic is in reality probably much weaker (see also Körner, 2012).

This prediction is also due to the nature of the model, which takes into account only the size characteristics and change in the distance, ignoring any qualitative aspect of mutual relations, which is, especially in the context of structural issues of both neighbouring regions, one of the factors influencing lower demand and supply. This is also confirmed by the fact that for the Ostrava-Bohumín motorway section, from which most contacts between the Ostrava region and Poland are realised (including those which are realised through the border crossing in Český Těšín/Chotěbuz), the model predicted a high and for the following decades probably unreal value, of more than 50,000 vehicles per day. From a methodological point of view, in order to eliminate the improbable values, it is possible to include in the model input data such measures like decreasing the size of centres in another state or quantifying the barrier of the state border, by which the mutual resistance of the centres is theoretically increased. The second reason for the high traffic load value in the Bělotín-Ostrava section is a generally assumed increase in the interaction between Ostrava and the surveyed centres of the Czech Republic, and also with the districts of Nový Jičín and Valašské Meziříčí, for which Ostrava will become better accessible because of the motorway.

Apart from the prediction of the D47 traffic load, it is possible to compare the results obtained from our model for the monitored network with real values for 2012 . In general, the model predicted a significant shift of traffic relations from the previous Ostrava-Příbor-Nový Jičín transit axis realised by the $\mathrm{I} / 56$ and $\mathrm{I} / 48$ roads, in favour of the D47. Compared to real data, the model predicted an even steeper drop of traffic intensities in these sections (by approximately $3,000-8,000$ ), especially due to the premise that all contacts would be already realised by the connection, which is more convenient in terms of time economy. It is obvious that this premise, necessary for the construction of the basic model, however, can not be objectively fulfilled, since many factors influence route preference, including the financial aspect concerning motorway fees. Similarly, in accordance with the real data analysis (see above), the model also predicted that the D47 would have only a limited influence on the traffic load in the Ostrava-Frýdek-Místek section. By contrast, the results obtained from the model predicted a higher traffic load, which was mostly influenced by the general increase of intensities caused by the selected distance parameters used for the model construction.

\footnotetext{
${ }^{7}$ Derived empirically, the value stated above corresponds to the values usually applied in gravity modelling.
} 
In addition to the above stated results, the model can also to a certain degree make up for the main absence of traffic load data on network edges, i.e. for the proportion of each relation on the overall traffic load. This procedure has also been applied in the above-mentioned study (Chmelík, 2008), where the author made an illustrative estimate of the proportion of each connection in the Příbor-Nový Jičín section, by which all the long-distance transport from/to Ostrava and the transit transport through the region, was realised in the surveyed year of 2000. Based on the results of the model, it is possible to state that traffic relations between Ostrava and other centres included in the model constitute $50 \%$ of the overall traffic burden on the monitored section. Next come (again strong - see above) transit relations with Katowice and Krakow with $35 \%$, and other relations between the inter-regional (e.g. Frýdek Místek-Prague) and micro-regional (e.g. Frýdek-Místek-Nový Jičín) centres with the remaining $15 \%$. These are, however, only approximate results, as it is practically impossible to verify them with real data with respect to directions.

\section{Conclusions}

This discussion of approaches to the assessment of effectiveness and societal benefits of a transport infrastructure project based on considering the spatial distribution and traffic interaction intensity as the major direct impacts, allows for pointing out significant differences between the situation in the Czech Republic and Western Europe. Especially in the AngloSaxon countries, the assessment of transport infrastructure projects is based on methods (reviewed in Hayashi, Morisugi, 2000), which take into account mainly time economy as the most significant factor causing changes in transport intensities. In the Czech Republic, this approach was not fully embraced, especially in the past. Factors other than transport effectiveness are often used for prioritisation, especially territorial preparedness (see Viturka et al., 2012), which is related to the ease of negotiation across the consulting points. This can be proved easily by the R35 expressway project, which has been for a long time presented by political representatives and transport experts as a condition necessary for connecting Bohemia and Moravia as an alternative to the motorway D1, but the pace of realisation has been very slow compared to other projects. A signal for improving prioritisation in the transport infrastructure of the Czech Republic can be seen in the project of transport strategies currently being prepared by the Ministry of Transport, as it should define priorities binding for transport infrastructure construction, based on the assessment of peoples' actual needs.

Another issue which precedes the prioritisation issue is data input, which is necessary for any relevant assessment. The restrictions of databases are not only an issue in the Czech Republic. The main problem is the lack of data on traffic flow, i.e. about the starting point and destination of traffic participants. This, though, is absolutely logical given the nature of individual transport. By contrast, the data on traffic intensity in individual sections are easily accessible from the national traffic census. These data, however, provide no information on direction and are therefore more difficult to use for assessing the impact of new connections in a given area. For this reason, they are often subsequently adjusted in order to fit the analyses, transport models and simulations.

The core of this paper was a case study in which we at first evaluated changes in transport intensities in concrete sections of a relevant road network, which might have been due to changes in route preference due to the opening of the D47. The results of the basic analysis, which capture the development of traffic intensities of passenger vehicles in the predefined sections, confirmed the intuitive premises about the redistribution of traffic relations in those centres for which the new connection offered a more time-saving alternative. In particular, a greater part of traffic flow in the Ostrava-Př́bor-Nový Jičín-Hranice axis was shifted to the new motorway. By contrast, the traffic on the OstravaFrýdek-Místek-Příbor route changed less significantly, which confirms the assumption that this section had not been used for supra-regional relations even in the past. This assumption is in conflict with some of the earlier proposals for connecting the Ostrava region on the motorway network only by the R56 expressway (see, e.g. Robeš, Růžička, 1998).

The general question is how to distinguish between the distributive and generative effects of new transport intensities on the D47, which is difficult, among other factors, also due to the necessity of assessing impacts on the competitiveness of major transport modes. Nevertheless, it can be assumed that a significant part of the traffic load is the shifted traffic (distributive effect), which can be supported both by the fact that traffic intensities between 2005 and 2010 stagnated (see Viturka et al., 2012), and by the fact that the commuter traffic flow from the Ostrava region streaming especially to Prague is much more than in other Czech regions realised by high-quality railway transport, which can compete with car transport. The process of transport induction (generative effect) will then probably be evident especially in those sections where residents of settlements near entrance ramps can potentially commute daily to other centres, especially Ostrava, due to the decrease in time needed for the travel. This assumption, though, should be confirmed first by detailed research in which it would also be possible to compare traffic intensity changes on motorways and expressways heading in a radial manner towards Prague, where the changes can be expected to be more dynamic.

The second part of the case study dealt with an evaluation of the utility and significance of construction, part of which is the prediction of traffic intensity values. In the case of the $\mathrm{D} 47$, the prediction was even more interesting because the decision-making bodies did not make any relevant assessments, and therefore it was not possible to compare alternatives or conclude that this project was needed more than the other ones. The accessible data on the traffic load in 2010 allowed for a comparison of the official prediction elaborated for RMD before the motorway opening, based on modelling in a specialized software in which the future growth rates of traffic intensities were included (ADIAS, 2001; RMD, 2009, 2012). These results were also compared with our own prediction based on a gravity model for the affected area. A partial aim of both predictions was to find out if the geographic application of this elementary form of the gravity model based on the selection of major interrelated centres in the region and relevant centres outside the region, and including also changes in the size and significance parameter, can compete with the output of software used by transport engineers. The results showed that the predicted values were overestimated, especially the values predicted in our model for the sections leading to Ostrava. This does not diminish the value of such predictions, since they were calculated with the assumption that the motorway would be completed, which was not yet the case by the 2010 traffic census, as has been already stated above. But, in this context, we should point to Körner's opinion (2012) that predictions are sometimes deliberately overestimated in order to push the motorway project through. 
Nevertheless, the results confirmed that the application of a basic gravity model can generate relevant and valuable output, especially when taking into account that after further adjustments of the input, it could be comparable to the official models based on which the factual decisions about transport infrastructure building are made. This is a key matter in the situation in which the complexity of the official models practically does not allow an intuitive review of the output data. It is also likely that the application of such models will still be topical given the permanent lack of the required more accurate directional data. And, since every model significantly generalizes reality, a sensitive interpretation of results and their critical assessment will continue to be a necessity.

\section{Acknowledgement}

This contribution was prepared from the research project number P404/12/1035: "Spatial Dynamics of Transport Relationships in the Settlement System of Czechia”, granted by the Grant Agency of the Czech Republic. The authors are much obliged for this generous support.

\section{References:}

ADIAS (2001): Dálnice D1 a D47 v úseku Holubice-Polsko. Stanovení intenzit dopravy - průvodní zpráva. ADIAS, Brno, 10 pp.

BANISTER, D., BERECHMAN, Y. (2001): Transport investment and the promotion of economic growth. Journal of Transport Geography, Vol. 9, No. 3, p. 209-218.

BARTOŠ, L. et al. (2010): Prognóza intenzit automobilové dopravy (TP 225). EDIP, 22 pp.

BAUEROVÁ, D., RAMÍK, J. (2004a): Modeling the Influence of the New Motorway D47 from Lipník to Ostrava by the Concept of Economic Potential of the Regions. In: Bulava, P. et al. [eds.]: Studies and Analyses of the Macro- and Microeconomic Systems Structures and Behavior Using the Economic-Mathematical Methods. VŠB-TU, Ostrava, p. 141-162.

BAUEROVÁ, D., RAMÍK, J. (2004b): Economic Potential of the Regions Based on Gravity Models. In: Bauer, L.: Proceedings of the $22^{\text {nd }}$ International Conference Mathematical Methods of Economics 2004, Masarykova univerzita, Brno, p. 16-21.

BLACK, W. R. (2003): Transportation: a geographical analysis. The Guilford Press, New York, 375 pp.

BRŮHOVÁ-FOLTÝNOVÁ, H. et al. (2008): Analýza každodenního dopravního chování dospělého městského obyvatelstva a nástroje regulace dopravy. Závěrečná zpráva z projektu MD 24/2006-430-OPI/3 z OP „Infrastruktura“ - Priorita 2 (2.4). Univerzita Karlova v Praze, Centrum pro otázky životního prostředí, 281 pp.

HALÁS, M. (2005): Dopravný potenciál regiónov Slovenska. Geografie, 110, No. 4, p. 257-270.

CHMELÍK, J. (2008): Modelování prostorových interakcí na příkladu Ostravska. Diplomová práce. Katedra sociální geografie a regionálního rozvoje PřF UK, Praha, 97 pp.

GROSCHE, T., ROTHLAUF, F., HEINZL, A. (2007): Gravity models for airline passenger volume estimation. Journal of Air Transport Managment, Vol. 13, p. 175-183.

GÜHNEMANN, A., LAIRD, J. J., PEARMAN, A. D. (2012): Combining cost-benefit and multi-criteria analysis to prioritise a national road infrastructure programme. Transport Policy, Vol. 23, p. 15-24.

GUTIÉRREZ, J. (2001): Location, Economic Potential and Daily Accessibility: An Analysis of the Accessibility Impact of the High-speed Line Madrid-BarcelonaFrench border. Journal of Transport Geography, Vol. 9, No. 4, Dublin, p. 229-242.

GUTIÉRREZ, J., URBANO, P. (1996): Accessibility in the European Union: the impact of the trans-European road network. Journal of Transport Geography, Vol. 4, No. 1, p. $15-25$.

HAGGETT, P. (2001): Geography - a Global Synthesis. Prentice Hall, London, 833 pp.

HAMPL, M. (2005): Geografická organizace společnosti v České republice: Transformační procesy a jejich obecný kontext. Katedra sociální geografie a regionálního rozvoje, PřF UK, Praha, 148 pp.

HAYASHI, Y., MORISUGI, H. (2000): International comparison of background concept and methodology of transport projects appraisal. Transport Policy, Vol. 7, p. 73-88.

HŮRSKÝ, J. (1978): Metody oblastního členění podle dopravního spádu: úvod do teorie předělů osobní dopravy. Rozpravy ČSAV, 6, Academia, Praha, 96 pp.

JEŘÁBEK,M., MARADA,M. (2003): Regionálněgeografické hodnocení území ovlivněného trasou dálnice D8 a výběr ukazatelů pro stanovení nepřímého užitku výstavby dopravní infrastruktury (příloha). In: Lehovec, F. et al.: Komplexní hodnocení užitku výstavby dopravní infrastruktury. Fakulta stavební, ČVUT v Praze, Praha, 18 pp.

JUREČKA, V. (2003): Přeměna „D47“v politicko-ekonomický fenomén. In: VI. Mezinárodní kolokvium o regionálních vědách, Masarykova univerzita, Brno, p. 79-85.

KÖRNER, M. (2012): K hodnocení přínosů vybraných tras silniční infrastruktury. Urbanismus a územní rozvoj, Vol. XV, No. 2, p. 35-36.

KRAFT, S., BLAŽEK, J. (2012): Spatial interactions and regionalisation of the Vysočina Region using the gravity models. Acta Universitatis Palackianae Olomucensis, Facultas Rerum Naturalium, Geographica, Vol. 43, No. 2, p. $65-82$.

KRAFT, S., MARADA, M., POPJAKOVÁ, D. (2014): Delimitation of nodal regions based on transport flows: case study of the Czech Republic. Quaestiones Geographicae, Vol. 33, No. 2, p. 139-150.

KUTA, V. (2000): Rozvojové problémy ostravské aglomerace. Magistrát města Ostravy - Útvar hlavního architekta, Ostrava, $253 \mathrm{pp}$.

LEE Jr., D. B. (2000): Methods for evaluation of transportation projects in the USA. Transport Policy, Vol. 7, p. 41-50.

LEHOVEC, F. et al. (2003): Komplexní hodnocení užitku výstavby dopravní infrastruktury. Fakulta stavební, ČVUT v Praze, Praha, 74 pp.

MATSUMOTO, H. (2007): International air network structures and air traffic density of world cities. Transportation Research Part E, 43, Elsevier, p. 269-272.

MARADA, M. (2008): Transport and geographical organization of society: Case study of Czechia. Geografie, Vol. 113, No. 2, p. 285-301. 
MARADA, M., KVĚTOŇ, V., VONDRÁČKOVÁ, P. (2010): Doprava a geografická organizace společnosti v Česku. Edice Geographica, ČGS, Praha, 165 pp.

MORISUGI, H. (2000): Evalution methodologies of transportation projects in Japan. Transport Policy, Vol. 7, p. 35-40.

NTC (2000): National Traffic Census 2000. [online] [cit. 25.02.2013] Available at: URL: www.rsd.cz/doprava/ scitani_2000/start.htm

NTC (2005): National Traffic Census 2005. [online] [cit. 25.02.2013] Available at: URL: www.scitani2005.rsd.cz

NTC (2010): National Traffic Census 2010. [online] [cit. 25.02.2013] Available at: URL: http://scitani2010.rsd.cz/

PRÁŠIL, M. (2007): Dálnice 1967-2007. Zvon, 134 pp.

PRESTON, J., O'CONNOR, K. (2008): Revitalized transport geographies. In: Knowles, R. [ed.]: Transport geographies: Mobilities, Flows and Spaces. Blackwell Publishing Ltd., Oxford, p. 227-237.

QUINET, E. (2000): Evalution methodologies of transportation projects in France. Transport Policy, Vol. 7, Elsevier Science, p. 27-34.

ŘEHÁK, S. (1992): Sídelně dopravní model ČSFR a jeho územní souvislosti. Geografický časopis, Vol. 44, No. 1, p. 59-72.

ŘEHÁK, S. (1997): Modely jako nástroj včasného varování. In: Patrik, M. [ed.]: Alternativní trendy dopravní politiky v ČR. Sborník ze semináře v Rybníku u Poběžovic. Český a Slovenský dopravní klub, Brno, p. 27-35.

ŘEHÁK, S. (2004): Geografický potenciál pohraničí. In: Jeřábek, M., Dokoupil, J., Havlíček, T. et al.: České pohraničí - bariéra nebo prostor zprostředkování? Academia, Praha, p. 67-74.

REPHANN, T. J. (1993): Highway Investment and Regional Economic Development: Decision Methods and Empirical Foundations. Urban Studies, 30, No. 2, p. 437-450.

RIETVELD, P., BRUINSMA, F. (1998): Is Transport Infrastructure Effective? Transport Infrastructure and Accessibility: Impacts on the Space Economy. SpringerVerlag, Berlin-Heidelberg, 383 pp.

RIETVELD, P., VICKERMAN, R. (2004): Transport in regional science: The "death of distance" is premature. Papers in Regional Science 83, RSAI, p. 229-248.

RMD (2009): Informační publikace o projektu D47. [online] [cit. 15.09.2010] Available at: URL: http://www.rsd.cz/doc/ Silnicni-a-dalnicni-sit/Dalnice/publikace-o-projektu-d47
RMD (2012): Informační publikace o projektu D47. [online] [cit. 02.08.2012] Available at: URL: http://www.rsd. cz/doc/Silnicni-a-dalnicni-sit/Dalnice/publikace-oprojektu-d47

ROBEŠ, M., RŮŽIČKA, J. (1998): Alternativní návrh koncepce rozvoje dopravních sítí České republiky do roku 2010. Český a Slovenský dopravní klub. [online] [cit. 25.09.2012] Available at: URL: http://dopravniklub. ecn.cz/texty_alter.shtml

RODRIGUE, J.-P., COMTOIS, C., SLACK, B. (2006): The Geography of Transport Systems. Routledge, London, $284 \mathrm{pp}$.

SAO Bulletin (2003): Auditing Action 02/10, Finanční prostředky vynaložené na rozvoj dopravních sítí v České republice. p. 122-131. [online] [cit. 25.09.2012] Available at: URL: < http://www.nku.cz/kon-zavery/K02010.pdf>

SAO Bulletin (2005): Auditing Action 04/25, Rozvoj dopravní infrastruktury v regionech soudržnosti Střední Morava a Ostravsko. p. 223-230. [online] [cit. 25.09.2012] Available at: URL: < http://www.nku.cz/kon-zavery/K04025.pdf >

SCHEJBALOVÁ, B., TEPEROVÁ, K. (1999): Co očekáváte od dálnice D47, Ostravané? Urbanismus a územní rozvoj, No. II, No. 5, p. 11-12.

SUCHÁČEK， J. (2005): Restrukturalizace tradičních průmyslových regionů $\mathrm{v}$ tranzitivních ekonomikách. VŠB-TU, Ekonomická fakulta, Ostrava, 221 pp.

VACHTL, M. et al. (2013): Dopravní sektorové strategie 2. fáze (souhrnný dokument). Ministerstvo dopravy, Praha, 305 pp. [online] [cit. 05.08.2013] Available at: URL: http://www.dopravnistrategie.cz/

VICKERMAN, R. (2000): Evaluation methodologies for transport projects in the United Kingdom. Transport Policy, Vol. 7, p. 7-16.

VICKERMAN, R. W., SPIEKERMAN, K., WEGENER, M. (1999): Accessibility and Economic Development in Europe. Regional Studies, Vol. 33, No. 1. p. 1-15.

VITURKA, M., PAŘIL, P., TONEV, P. (2012): Hodnocení účelnosti projektů výstavby dopravní infrastruktury (Případová studie dálnic a rychlostních silnic České republiky). Urbanismus a územní rozvoj, Vol. XV, No. 2, p. $28-34$.

ZAHRADNÍK, P. (2003): Zhodnocení přínosů a nákladů dálnice D47 na ekonomický a sociální vývoj České republiky, dotčených regionů, měst a obcí: kvalitativní a kvantitativní analýza. 43 pp. [online] [cit. 15.12.2007] Available at: URL: www.darius.cz/ag_nikola/zahradnik_studie.doc

\section{Authors' addresses:}

Mgr. Jakub CHMELÍK, e-mail: jakub.chmelik@natur.cuni.cz RNDr. Miroslav MARADA, Ph.D., e-mail: miroslav.marada@natur.cuni.cz Department of Social Geography and Regional Development, Faculty of Science, Charles University in Prague Albertov 6, 12843 Praha 2, Czech Republic

Initial submission 2 October 2013, final acceptance 26 September 2014

Please cite this article as:

CHMELÍK, J., MARADA, M. (2014): Assessment of the impact of a new motorway connection on the spatial distribution and intensity of traffic flows: A case study of the D47 motorway, Czech Republic. Moravian Geographical Reports, Vol. 22, No. 4, p. 14-24. DOI: 10.1515/ mgr-2014-0020. 